\title{
¿PACHECO O HERRERA? LA CONSTRUCGIÓN EDITORIAL DE VERSOS (1619)
}

\author{
PACHECO OR HERRERA? THE EDITORIAL \\ CONSTRUCTION OF VERSOS (1619)
}

\author{
Pedro Ruiz Pérez \\ Grupo PASO \\ Universidad de Córdoba \\ fe1rupep@uco.es \\ orcid: 0000-0002-1950-9136
}

Resumen: Se plantea una perspectiva complementaria en la cuestión textual de Herrera a propósito de Versos. En lugar del cotejo de variantes en las piezas, se hace una aproximación al conjunto desde la materialidad del libro, se pone en relación con el contexto de la imprenta sevillana y la situación sociocultural de la ciudad, y, finalmente, a partir de estos datos se revisan las declaraciones prologales. Las dudas sobre una intervención profunda por parte de Pacheco en la ordenación editorial se incrementan al considerar su significación y novedad, que sólo puede atribuirse a Herrera.

Palabras clave: Fernando de Herrera; Versos; Francisco Pacheco; imprenta; dispositio.

Abstract: This study offers a complementary perspective on the textual problem of Herrera's Versos. Instead of collating variants in the poems, it approaches the question from the material features of the book itself. It then takes into account the characteristics of the Sevillian printing press and the socio-cultural situation of the city. In the context of the data gathered in this way, it finally re-reads the statements made in the prologue. Doubts about Pacheco's extensive editorial intervention increase when the significance and novelty of the presentation are taken into account, for they are aspects which can only be attributed to Herrera.

Keywords: Fernando de Herrera; Versos; Francisco Pacheco; printing press; dispositio.

Recepción: 17 de abril de 2020; aceptación: 21 de octubre de 2020.

D.R. () 2022. Nueva Revista de Filología Hispánica Licencia Creative Commons Attribution-NonCommercial (CC BY-NC) 4.0 International 
Más de un siglo después del estudio de Adolphe Coster (1908) y sus ediciones de los textos de Herrera (1908 y 1914)*, continúa siendo objeto de debate el problema textual que el estudioso francés introdujo, al actualizar para la filología del siglo xx las suspicacias iniciadas por Quevedo acerca de la autoría de las composiciones de Versos y el grado de intervención que tuvo Pacheco en la configuración de la obra. En la práctica totalidad de los casos las aportaciones críticas han tomado como objeto las variantes ofrecidas por los poemas en sus diferentes versiones, cuando no el estadio redaccional de los poemas publicados en 1619 y su relación con un pretendido horizonte de caracterización estilística del poeta sevillano ${ }^{1}$. El balance final del cúmulo bibliográfico originado en el debate puede considerarse bastante parcial, en tanto que la focalización sobre los detalles de los poemas ha dejado en penumbras el análisis y la valoración intrínsecos de la edición póstuma como realidad material. Para contribuir a una ampliación de la perspectiva he ensayado una lectura hermenéutica del discurso resultante de la dispositio del corpus y la secuencia de lectura que plantea la división en tres libros (Ruiz Pérez 2021). Desde una vertiente complementaria, planteo ahora otras vías de acercamiento a la elucidación del alcance de la labor de Pacheco como editor de Versos. Son vías de distinto cariz que exploran elementos y circunstancias en torno a los poemas impresos, e incluyen aspectos de bibliografía material, el discurso paratextual en su conjunto y el contexto sociocultural, la coyuntura histórica en que el volumen sale de las prensas hispalenses. Con los datos aportados ratifico el juicio expuesto en el artículo citado e insisto en la atribución al poeta de la singular dispositio de su corpus final, como resultado de su morosa y constante labor de lima y su preocupación por el sentido de su poesía.

\section{UN PROYECTO EDITORIAL: REALIZACIÓN Y MARCO}

En el primer estrato de aproximación podemos colectar algunos indicios a partir de las características tipográficas del volumen,

* El marco de este trabajo es el proyecto Biografías y polémicas: hacia la institucionalización de la literatura y el autor (SILEM II), del Plan Estatal de I+D+i, RTI2018-095664-B-C21.

${ }^{1}$ Puede encontrarse un buen panorama de la situación en Macrí 1972, pp. 145-167, complementado por Cuevas 1985, pp. 87-99. La actualización más reciente se encuentra en Hernández Lorenzo 2020. 
sus declaraciones explícitas y los datos de su impresión en el panorama de los talleres sevillanos y su mercado editorial.

\section{Algunos datos sobre la composición del volumen}

Sobre todo en comparación con el cuidado con que se compuso el volumen de Algunas obras, con el propio Herrera al pie de las prensas y aun de la fundición de tipos, la resolución tipográfica de Versos no es especialmente brillante. El hecho no se desvía de lo común en el estado de la imprenta sevillana del momento, en el que me detendré más adelante. Al margen del abandono de los criterios ortográficos y prosódicos del poeta, las erratas y el estado de los tipos de imprenta, sobre todo en las cursivas, denotan que el trabajo en el taller no se realizó con excesivo esmero, pese a que transcurrieron más de dos años entre la licencia y la tasa. No fue un período dedicado a las minucias de la impresión; más bien obedecería a una demora en busca de la financiación necesaria. Por ello, una vez conseguida ésta, la materialización del libro pudo haberse hecho con alguna urgencia y sin lujos, quizá por no retrasar mucho su aparición respecto a la de las Rimas de Jáuregui, en la primavera de 1618, cuando ambas obras habían obtenido la licencia casi al mismo tiempo, en septiembre de 1617. Dificultades y prisas de última hora, sin embargo, no fueron óbice para que algunos detalles dejaran entrever que al menos en el diseño del libro sí se puso un cierto esmero, en particular en lo tocante a la operativización de su estructura.

Con un valor determinante relativo, podría ser revelador el abundante número de casos en que el verso final de una elegía cierra la página, interpretable en términos de una voluntad de dar realce a las composiciones en que se detiene el fluir discursivo de los sonetos y se articula su desarrollo argumental. Más significativa me parece la decisión de elevar a titulillos no los nombres del autor y la obra, como era uso habitual, sino la división en libros, como si ésta fuera marca de lectura con valor semántico y funcional. En todo caso, la decisión subraya una división estructural del poemario previa a la cuenta del original y las demás labores tipográficas, una destacable pauta en la organización del volumen correspondiente a la fase editorial en que el texto se ordena y se fija ne varietur, aun sin contar con su traducción a la forma de la imprenta. Con ran- 
go de hipótesis, no de certeza absoluta, estos datos nos llevan a pensar en una ordenación de la obra anterior a 1617, paralela a la voluntad de Jáuregui de seleccionar y ordenar una parte de sus versos y coincidente con ésta en el inicio de los trámites para su publicación, si bien la de Versos hubo de demorarse casi dos años y medio, para lo que sólo cabe aducir razones de índole económica, como no dejaba de ser frecuente entre los poemarios de estas décadas. Y bien podrían relacionarse estas dificultades materiales con la mejorable pulcritud de la labor impresora, bien por las urgencias, bien por la falta de los recursos necesarios para buscar una solución más primorosa en lo material. Si la hipótesis no es muy errónea, el relativo descuido de la imprenta iluminaría, a la inversa, un marcado designio en la estructuración de la obra, en su sentido poético.

El encargo de la impresión a Gabriel Ramos Bejarano no plantea contradicciones con lo expuesto. El perfil del tipógrafo responde a lo que Pacheco necesitaba dentro de sus posibilidades. Presente en Sevilla desde 1609, diez años después han salido de su taller una treintena y media de títulos ${ }^{2}$, lo que puede ser un aval para desempeñar con solvencia lo encomendado. En su experiencia, Ramos Bejarano ha mostrado su instinto para el trabajo y su capacidad de adaptación. No dudó en abandonar Salamanca para trasladar a Córdoba la impresión de las Obras de Pérez de Oliva, a instancias de su tío y editor, Ambrosio de Morales, quien también le encomendó la impresión de su Crónica. En esa ciudad permaneció hasta que la necesidad de subsistencia le llevó a un foco editorial más activo, del que también se movió, para volver a Córdoba en $1620^{3}$, justo después de sacar a luz Versos, y trasladarse al año siguiente a Marchena para una impresión ocasional, seguramente, ya que ese mismo año se registran

${ }^{2}$ Los 36 contabilizados por Escudero y Perosso (1999) entre 1610 y 1619 tienen relativa correspondencia con los 37 que la BNE computa entre sus fondos, incluidas una cronología y una geografía más amplias, pero sin carácter exhaustivo (http://datos.bne.es/persona/XX1082378.html [consultado el 13 de abril de 2020]). No ofrece variación significativa Domínguez GuZMÁn (1992).

${ }^{3}$ El desplazamiento venía justificado por tratarse de un grueso tomo de más de 900 páginas en folio que contenía los Discursos para todos los Evangelios de Gaspar López Serrano, descrito por Valdenebro y Cisneros (2002; entrada 103). El dato pone de manifiesto la capacidad y el sentido empresarial del impresor, así como su flexibilidad ante formatos y materias, aunque con un acusado interés por las tareas de consideración, como la colección herreriana. 
cinco títulos con su pie de imprenta en Sevilla. Era, pues, una referencia destacada en los finales de la década y una garantía de respuesta a la demanda por su capacidad de adaptación, sin ser descartable que en ello interviniera la colaboración con otras casas tipográficas o el apoyo mutuo en la elaboración material, como indicaría la presencia al final de los preliminares de la marca del impresor, aún en activo, Luis Estupiñán, sin otra función que la de llenar, frente al horror vacui, una página, que quedaba completa con el tamaño de este escudo.

Parte importante de la preparación editorial, en este caso claramente ajena a un Herrera difunto y cercana a los usos académicos de Pacheco, es el denso aparato de preliminares que acompaña a los versos. En ellos se concita un buen número de nombres señeros, entre aprobadores, prologuistas, el propio editor y el dedicatario, y las implicaciones de cada uno de ellos y del conjunto no dejan de ser reveladoras de una intención manifiesta, que tampoco se soslaya en las declaraciones que en las mismas encontramos. Aunque son bien conocidas, las aportaciones de Rioja y Duarte se han analizado sobre todo en busca de datos acerca de las peripecias textuales, por lo que queda un margen para rastrear en ellas indicios del designio editorial que mueve la aparición de Versos. Al hilo del debate sobre el lugar de los afectos en la poesía herreriana, Rioja se sitúa en una clave petrarquista, desde la que exalta la temática amorosa y sitúa en relación con ella los rasgos de canciones y elegías, que le sirven para evocar su paralelismo con los modelos clásicos; en su veredicto se destaca una imagen de Herrera como poeta erudito, capaz de combinar la verdad y el ornato, partiendo desde una imitatio que cultiva por medio del uso de los excerpta, hasta traducirla en una emulatio que supone la superación de los paradigmas grecolatinos. Por esta razón se justifica el estilo levantado, por más que disimule los afectos, en el que cobran valor poético los empleos del hipérbaton y otras figuras que rozan la oscuridad, pero siempre sin atentar contra el aptum, más bien como manifestación de una poética culta.

En esta línea de discurso se inscribe de manera coherente la insistencia en la conocida práctica de reescritura a que el poeta sometía sus versos, lo que lo aleja del más extendido uso de la dispersión de una poesía de circunstancias que, de agruparse, lo haría de una manera inorgánica. Como al paso, aduce a manera de muestra de la facundia creativa de Herrera el que hayan quedado sin publicar otros textos, como los amores de 
Lausino y Corona, varias églogas y los versos octosilábicos, lo que significa que, pese al presunto naufragio textual, se conservan composiciones que no han entrado en el volumen de Versos, aun cuando cumplen esta condición. O, lo que es lo mismo, la compilación no obedece a una voluntad completiva, sino a una selección acorde con un carácter orgánico. El testimonio no apunta precisamente a que Pacheco hubiera tenido una intervención de gran calado en la definición estructural de la obra impresa en 1619. Si hubiera abrigado la intención de culminar unas "obras completas" de Herrera, sin duda lo habría anunciado de alguna manera en la entrega de 1619. Si no pretendía hacerlo, no tiene mucho fundamento pensar en que hubiese emprendido una labor de selección y combinación de perfiles tan nítidos.

Duarte, por su lado, orienta su texto a una altura más teórica y ofrece al sesgo algunas posibles motivaciones para la decisión editorial de Pacheco o, al menos, para las claves con que ésta se presentaba veinte años después de la muerte del autor. Sus palabras han sido aducidas como testimonio de cargo, cuando exalta la empresa editorial y atribuye a su promotor una activa labor de adición, por haber "recogido con particular diligencia y cuidado algunos cuadernos y borradores que escaparon del naufragio en que pocos días después de su muerte perecieron todas sus obras poéticas, que él tenía corregidas de última mano y encuadernadas para darlas a la imprenta" (1619, ff2vff†3r). La referencia a que Herrera tenía ultimada su obra es menos reveladora que la que alude a su voluntad de darla a la imprenta, que no puede ser un tópico sin base cierta a tenor de lo infrecuente de esta actitud entre los poetas cultos de su generación y aun de la siguiente, si exceptuamos a Lope. Por ello alaba que Pacheco "con tantas veras haya procurado restaurarla" (esto es, devolverla a su imagen primitiva), y hay que situar en este contexto el que "cumplió lo que faltaba de otros papeles sueltos": todo parece apuntar a que Herrera dejó un libro preparado, ultimado desde su estructura hasta la última corrección, y eso era lo que Pacheco había restaurado, luego de subsanar deterioros más o menos grandes a partir de otros testimonios. Sin embargo, completar no es componer.

En la tarea del editor hubo descuidos fehacientes - hay varios casos de sonetos repetidos, en dos versiones y dos posiciones diferentes- - pudo haber alguna adición o una reparación no del todo acertada - bien por enmienda ope ingenii, bien por el recurso a un borrador desechado por Herrera o 
corregido con posterioridad. En cambio, estaba lejos de haber intervenido en la dispositio; al menos, no se menciona nada en este sentido, y ello nos permite mantener la idea de que lo que encontraron los lectores en 1619 debía de acercarse bastante a la voluntad última del poeta, cuando menos en su composición estructural. Otra realidad, la de una especie de cartapacio de acarreo sin mucha relación con la obra auténtica de Herrera, hubiera concertado mal con la consideración de su excelencia poética, que le elevaba a la condición de "hijo insigne de nuestra ciudad" $\left(1619, * * * 1 \mathrm{r}^{4}\right)$ y lo convertía en la pluma de Duarte en argumento para una vindicación de la poesía, en la línea argumental de los panegíricos extendidos en esas décadas. En su misterioso y arcano valor cobra sentido la justificación y aun defensa de una cierta oscuridad en el texto, ligada a una argumentación política que vincula la altura de la lengua a la del imperio, en unas circunstancias bien distintas a las que enmarcaron la conocida formulación nebricense. En síntesis, el texto de Duarte, bajo ciertas afirmaciones que parecen apuntar en otra dirección, nos deja la imagen de un Herrera ocupado en la composición de un libro de poesía que debió de dar por acabado, ya que pensaba en su impresión, y la imagen complementaria de un Pacheco empeñado en restaurarlo en su esencia, aunque para ello hubiera de recurrir, con dispar fortuna, a testimonios de desigual valor con los que "remendar" los deterioros derivados de una azarosa y poco aclarada transmisión. Y todo ello como base para una defensa de la poesía, que parece tener un lugar de privilegio en el entorno sevillano.

Una muestra destacada y selecta de la república literaria hispalense se completa en los paratextos de Versos al sumar a los mencionados los nombres de Soria Galvarro y Pedro de Valencia -en el caso del zafreño, muy relacionado con Sevilla por medio de Arias Montano-, como responsables de sendas aprobaciones, y la figura mecenática del aún conde de Olivares, además del propio Pacheco, quien ejerció con coherencia su responsabilidad en el impulso de la edición y en el modo de otorgarle un valor pragmático y programático. Por ello hay algo de salto en el vacío al negarle una paralela coherencia a

${ }^{4}$ Cotejando con la edición de Cuevas (1985), sigo el texto de la princeps (Herrera 1619) por el ejemplar digitalizado de la Biblioteca Universitaria Alessandrina de Roma (https:/ / books.google.es/books?id=cyZhbj2eioQ$\mathrm{C} \& d q=$ FERNANDO + DE + HERRERA $\%$ 2BVERSOS\&hl $=$ es\&source $=$ gbs navlinks_s). Modernizo grafía, acentuación y puntuación. 
la hora de tratar los escritos de Herrera, siempre dentro de las particulares coordenadas en que se presenta el texto y la sintonía poética e ideológica que propone en el proyecto editorial culminante en la aparición en 1619. Antes de detenerme en las declaraciones del propio Pacheco sobre su labor conviene hacerlo justamente en ese contexto en el que aparece la edición y en el que se mueve el entorno letrado de la ciudad del Betis.

\section{La imprenta sevillana hacia 1619}

Cuando la segunda década del siglo XviI se acerca a su final, los rescoldos de los círculos académicos que brillaron en las generaciones precedentes, sin alcanzar la categoría de Mal Lara, el canónigo Pacheco y el propio Herrera, mantienen un notable vigor si lo comparamos con el mucho más acusado declive de la imprenta sevillana, que padece con más antelación el desplazamiento a la corte del foco cultural, tanto en su dimensión creativa como en la del funcionamiento del mercado editorial. El declive de la imprenta sevillana se manifiesta en términos cuantitativos, pero la evidencia es mucho mayor si atendemos al catálogo de sus realizaciones, muy lejos ya de los tiempos en que de sus prensas salían los productos que dinamizaron el sistema genérico, particularmente en la prosa de ficción, o que canalizaron la producción científica en torno a la Casa de Contratación. Como refleja Escudero y Perosso en su tipobibliografía (1999), la nómina de títulos está copada por relaciones de sucesos y pliegos de mínima entidad, por libros y textos de surtido para la liturgia o la vida religiosa, por obras de derecho o algún ocasional tratado práctico, por glosas diversas y un número creciente de sermones, en una actividad dominada en los años inmediatos a Versos por la amplia producción de impresos de diverso tipo y condición relacionados con el debate inmaculista. Valga como referencia cercana al caso que nos ocupa que entre los 341 títulos catalogados por Escudero entre 1600 y 1619 sólo se contabilizan 11 volúmenes de poesía de autor; prescindiendo de los de Jáuregui y Herrera, los nueve restantes son en su práctica totalidad poemas épicos o volúmenes de materia religiosa, cuando no se aúnan ambas naturalezas.

El dato no es cualitativamente muy distinto a lo observable en períodos anteriores o en otros entornos geográfico-culturales (Ruiz Pérez 2001 y 2011), dada la aún en estos momen- 
tos mantenida resistencia de la mayoría de los poetas de cierto nivel cultural a dar sus obras a la imprenta. Sí resulta revelador de la distancia existente entre una práctica poética que no podía considerarse declinante y una imprenta bastante impermeable a esta realidad, que amenazaba con agotarse - como lo fue haciendo paulatinamente- con la falta de los espacios académicos que mantuvieron su vigencia en el siglo anterior. Con la atracción efectiva ejercida por Madrid para los ingenios sevillanos, la imprenta y el mercado del libro podían vislumbrarse como una oportunidad de hacer presente la actividad poética en su marco social, tal como cuatro décadas antes planteó Andrea Pescioni en el mismo proyecto en el que Herrera incluyó Algunas obras (Núñez Rivera 2000). Es razonable pensar que Pacheco quisiera poner la recuperación de los versos de Herrera a contribución de una empresa relacionada con esta situación, en la que también podría haberse inscrito, aunque con una dimensión más individual y distinta, la salida editorial de Jáuregui, a la que habremos de volver. Sin embargo, si ésta fue la intención de Pacheco, no dejaría de encontrar dificultades para llevarla a cabo, y no sólo por la problemática textual.

De nuevo con Escudero y Perosso (1999), podemos constatar entre un buen número de impresores de actividad regular (Francisco Pérez, Luis Estupiñán, Rodríguez Gamarra, Clemente Hidalgo, Francisco de Lira... o el propio Ramos Bejarano) la ausencia casi total de libreros que costearan las impresiones; sin contar agentes institucionales (religiosos o administrativos), sólo en tres de los 341 registros mencionados se alude a dicha función, lo que supone, amén de una falta de interés o de recursos económicos, que los costes debían correr por cuenta de quienes tenían la voluntad de ver un texto impreso. Pacheco se encontraría con este obstáculo, como inducíamos de los datos de bibliografía material, y viene a ratificarlo el descubrimiento y estudio de un documento con funciones de contrato de imprenta. Juan Montero y Marta Cacho (2014) evidencian a la luz del registro de escribanía la voluntad de Pacheco de hacer en 1623 sendas ediciones de la Relación de la guerra de Chiprey el Tomás Moro de Herrera $^{5}$ con un impresor distinto al de 1619; lo

${ }^{5} \mathrm{Ni}$ estaban anunciadas en 1619 como parte de un proyecto programado de antemano, ni se trata de obras en verso, por lo que su dimensión es completamente distinta, sin cuestionar lo señalado antes acerca de un poco probable interés de Pacheco por publicar toda la poesía de Herrera. 
interesante en este momento es constatar, según se desprende del documento, que el pintor metido a editor conservaba aún al menos doscientos ejemplares de Versos, lo que apunta a que la costa de la edición corrió por su cuenta. Quede para más adelante la implicación del dato en lo relativo a la difusión del volumen previo, para retener ahora la constatación de que Pacheco hubo de poner en juego su propio pecunio, con las implicaciones que ello tenía en la demora de la aparición del libro, pero también en la incongruencia entre una devoción de alto precio y el intento de montar una superchería.

\section{En el proceso de publicación}

Los datos conforman, pues, un escenario muy connotado, y en él el diálogo del volumen herreriano con las Rimas de Jáuregui resulta etimológicamente dramático y revelador de algunas parcelas desatendidas. Es de notar, en primer lugar, que el volumen de 1618, con trámites casi simultáneos a los de Versos, también aparece sin indicación de librero y sin dedicatoria en la portada ni en los preliminares generales; sólo dentro de los pliegos previos a los paginados, al comienzo de los versos de la versión del Aminta de Tasso, encontramos una dedicatoria de esta pieza a don Fernando Enríquez de Rivera, duque de Alcalá, como vestigio de una decaída actividad académica en los entornos nobiliarios; no tenemos constancia de la efectividad del ofrecimiento. E ilustrativo resulta que lo dirigido al noble sea la parte de la obra de perfil más humanista, traducción de un texto italiano con rasgos de adaptación cortesana de un modelo de raíces clásicas y corte dramático y semiteatralizado. En cambio, el cancionero de rimas humanas y divinas quedaba, además de sin patrocinio financiero, sin el amparo de un ilustre destinatario.

La similitud de circunstancias con la edición de Pacheco subraya las líneas contextuales de una Sevilla posacadémica y en busca de redefinir el lugar de la poesía en sus prácticas socioculturales. Por esta razón Jáuregui se ve precisado de poblar con elementos de apoyo los preliminares de su libro y abrirlo con una "Introducción" que tiene mucho de justificativa. En sus breves páginas hallamos pasajes y argumentos con ecos en el contorno de Versos, comenzando por la caracterización de lo que sigue como unas rimas "que me pareció entresacar de algunos borradores" (en la primera frase de su "Introducción”), para 
proponer a continuación una lectura de la compilación que sigue aplicando el patrón de la trimembración, segmentando la adaptación del Aminta, las composiciones "humanas" (que incluyen la versión de La Farsalia) y, en la cúspide, las "obras sacras". En correspondencia, las pretensiones de fijar una preceptiva poética también recurren a la misma división numérica, al establecer como partes de la poesía el alma, el cuerpo y el adorno, identificadas con el asunto, las sentencias y las palabras, esto es, el esquema clásico de inventio, dispositio y elocutio como partes de la retórica atinentes al texto escrito. La comunidad de pensamiento con los otros ingenios sevillanos presentes en los preliminares de Herrera se intensifica al sostener que "el artificio de la locución y verso es el más proprio y especial ornamento de la poesía y el que más la distingue y señala entre las demás composiciones, porque la singulariza y la reduce a su perfecta forma ${ }^{6}$ con esmerado y último pulimento" (Jáuregui 1618, [f. 3r-3v]). Como hará (o estaba haciendo) Duarte, Jáuregui defiende el valor de una poesía erudita (de erudere, "eliminar las rudezas') en todas sus partes, aunque se mantiene dentro del estrecho sentido del decoro o aptum que le llevara a la redacción del incendiario Antídoto.

La relación percibida entre estas dos obras, en su cercanía y en sus diferencias, se manifiesta en esa huella de lectura que en muchos casos trasladan las prácticas de encuadernación. Así sucede en el que ahora es el ejemplar R/7730 de la BNE, un facticio en el que se agrupan, en un orden que puede aludir a preferencias, más que a cronología, Versos y Algunas obras de Herrera, una curiosa carta y las Rimas de Jáuregui ${ }^{7}$. Sobre el significado de la agrupación y el orden se añade el contenido de lo que podemos considerar una "reseña epistolar". En ella el

${ }^{6}$ Las ideas poéticas de Jáuregui han quedado perfectamente sintetizadas en el definitivo estudio de Rico García (2001); retengamos ahora la noción de "perfecta forma", que volveremos a encontrar en la pluma de Pacheco.

7 No hay notas marginales de lectura; sí un buen estado de conservación y una banderita al final del Aminta (p. 81), que contiene una corrección extendida en muchos de los ejemplares de la Rimas: se sustituye el mesquina del original italiano trasladado a la impresión sevillana por un zagala, que en nuestro caso aparece cuidadosamente caligrafiado en el papelito pegado sobre la página (accesible en Biblioteca Digital Hispánica). La carta fue editada por López EsTRAda (1955) a partir de la copia incluida en el Libro de varios tratados de graciosidad y erudición, compilado por Pacheco y conservado en la Biblioteca Universitaria de Sevilla, H/Ra/0158, ff. 261-268. 
cortesano Antonio Hurtado de Mendoza se dirige al sevillano Francisco de Calatayud, curiosamente autor del primero de los poemas laudatorios de las Rimas, para satirizar algunos aspectos de la obra, en fecha tan cercana a su aparición como el 29 de julio de 1618, poco más de dos meses después de la publicación del texto en Sevilla. El interés de los juicios de Hurtado de Mendoza y su reflejo de las diferencias poéticas entre el centro cortesano y la periferia sevillana cede ahora ante algo más significativo: los matices se colocan sobre los aspectos de la poética erudita donde se apartan Jáuregui y los administradores editoriales de Herrera, y alguien plasmó en la encuadernación conjunta - en el siglo XVII, a juzgar por las cubiertas y la letra de la anotación en el canto- la conciencia de unas relaciones no exentas de tensión y presentes, con toda probabilidad, en la empresa editorial de Pacheco.

\section{La firma de Pacheco}

De entre las declaraciones que el pintor incluye en los preliminares de Versos, la crítica ha destacado una afirmación, más llamativa que inequívoca, en el cuarteto inicial de su soneto laudatorio:

Goza, oh nación osada, el don fecundo que te ofresco, en la forma verdadera que imaginé, del culto y gran Herrera, y el fruto de su ingenio alto y profundo.

Ya que amaste el primero, ama el segundo, pues pudo el uno y otro, en su manera, aquél honrar del Tajo la ribera, éste, del Betis, y los dos, el mundo.

El dulce y grande canto, el espumoso océano a naciones diferentes lleve y dilate ufano su pureza,

por que tu nombre ilustre y generoso no invidie ya otras liras más valientes, ni del latino o griego la grandeza $(1619, * 1 r)$.

La frase "te ofrezco en la forma verdadera / que imaginé" ha sido tomada en un sentido tan literal como descontextuali- 
zado y anacrónico, y se halla necesitada, por tanto, de revisión ${ }^{8}$. Aunque Pacheco no fuera un poeta excelso, no era un ignorante de las leyes del verso, por lo que no se debería obviar el efecto del encabalgamiento. Se ofrece así una primera lectura, apoyada en la prosodia métrica, que deja exenta y en final de verso "la forma verdadera", haciéndola rimar, además, con "Herrera", tras un marcado hipérbaton que articula todo ese primer cuarteto de manera inhabitual. La disposición inclina la lectura para atender a la tensión entre el orden gramatical, el resultante de la anástrofe y el que marca la escansión de las líneas versales. Se ilumina de este modo la polaridad entre verdadera e imaginé, con un aparente oxímoron que ha de inducir a la reflexión y el análisis. El primer término no se presta a equívoco, sí el segundo. Sin embargo, se ha venido prescindiendo de la referencia a la verdad, en cuanto que correspondencia con el original, para resaltar la acción imaginativa, como falseamiento, sin tomar en consideración que la noción en las primeras décadas del siglo xviI está muy lejos de corresponderse con su sinónimo romántico, más cercano a la creación ex nihilo y la separación de la realidad material. No desdeñó el primer sentido Pablo de Céspedes, tan cercano a Pacheco, y en él insistió explícitamente en las octavas en que se dirige a Pacheco para trazar un elogio de Herrera:
Tú, que del torpe olvido soñoliento levantaste la imagen verdadera contra la ley del tiempo y movimiento al divino Fernando de Herrera; a ti, pues, toca con sublime acento celebrar sus despojos de manera que no envidie de Máusolo la gloria ni de la antigua Menfis la memoria (Chiappini 1985, p. 173).

Pacheco incluyó el texto como celebración funeral al final del apartado dedicado a Herrera en el Libro de retratos, y la cita nos lleva al ámbito de la teoría contemporánea de las artes visuales para indagar en el sentido que en ella tenía el imaginar.

${ }^{8}$ Se atuvo a una lectura literal Blecua (1970, pp. 117-120). Con menos inclinación a desautorizar a Pacheco, MAcrí (1972, pp. 150-153) ha dedicado un documentado y atinado comentario sobre el sentido de la expresión; aprovecho sus observaciones y añado otros argumentos. 
El verbo de acción y la designación de su agente se forman a partir de la noción y el término de imagen, que en esencia es el reflejo de algo que puede resultar invisible y respecto a lo cual no guarda precisamente una relación de infidelidad, sino que resulta su representación sin voluntad de distorsión ni engaño. Con tal valor se conciben las imágenes sagradas, a las que se dedica el capítulo XI del libro primero del Arte de la pintura, "De la pintura y de las imágenes y de su fruto, y la autoridad que tienen en la Iglesia Católica"; y conviene recordar en este punto el puesto inquisitorial ostentado por Pacheco como celador de la ortodoxia de las imágenes. Se hace difícil pensar que en tal tesitura pudiera usar imaginé con un sentido de fabulación. Por su parte, pocos años antes de Versos, Covarrubias asienta las bases lexicográficas de este concepto, que hace derivar de imago, con su valor de repraesentatio, y pasa a ilustrarlo directamente con la doctrina inequívoca de Tomás de Aquino, para quien "Imago proprie dicitur quod procedit ad similitudinem alterius; id autem a quo procedit dicitur proprie exemplar", e insiste a continuación en el caso de las imágenes sagradas, como "las figuras que nos representan a Cristo nuestro señor, a su benditísima madre y virgen santa María, a sus apóstoles y a los demás santos" (1979, p. 732), con una idea de cercanía a la verdad que las convierte en modelo de imitación. Así el término se acerca al concepto del retrato, tal como el propio Pacheco lo concibió en su Libro de verdaderos retratos, con su insistencia en que las imágenes proceden directamente del original y tienen, por tanto, un valor de fiel exactitud.

De nuevo Céspedes se hace eco de este sentido, cuando define la pintura como representación de la realidad, interrogándose por su principio: “¿El dibujo, que él solo representa / con vivas líneas, que redobla y parte, / cuanto el aire, la tierra y mar sustenta?" (I, wv. 10-12; Chiappini 1985, p. 157); o al reformular la teoría microcósmica del hombre como imagen del mundo a partir del Génesis: "y l'aura simple de inmortal sentido / inspiró dentro en la mansión interna, / que la exterior parte avive, y mueva / los miembros fríos de la imagen nueva" (II, w. 6-8; Chiappini 1985, p. 158). Y recuérdese que, según la Biblia, Yahvé creó al hombre "a su imagen y semejanza", con fórmula de reduplicación sinonímica. Aplicado directamente a la pintura, Céspedes es más explícito:

Del natural pretende alto motivo seguir, que a sólo estudio no se entrega; 
del natural recoge los despojos de lo que pueden alcanzar tus ojos.

Busca en el natural y, si supieres buscarlo, hallarás cuanto buscares; no te canse mirarlo, y lo que vieres conserva en los diseños que sacares; en la honrosa ocasión y menesteres te alegrará el provecho que hallares, y con vivos colores resucita el vivo, que el pincel e ingenio imita.

No me atrevo a decir ni me prometo todas las bellas partes requeridas hallarse de contino en un sujeto todas veces, sin falta recogidas; aunque las cría sin ningún defeto, a todas en belleza preferidas, naturaleza, tú entresaca el modo $\mathrm{y}$ de partes perfetas haz un todo

(XIX, vv. 17-32; Chiappini 1985, pp. 170-171).

Guillermo Serés (1994) ha estudiado los matices de la imaginación respecto a la fantasía ${ }^{9}$ desde el punto de vista epistemológico, y David H. Darst (1985) ha indagado en la proyección del concepto en la teoría de la pintura, y no he de volver sobre sus pasos. Baste sintetizar que la imaginación se concibe como la capacidad de trascender las apariencias para acercarse al modelo ideal, antes de proyectarlo en el lienzo o, como en el caso que nos ocupa, llevarlo a la imprenta. Desde esta posición teórica, compartida por Pacheco, la imagen no se entiende como una falsificación, sino como un acercamiento a la realidad trascendente, a partir de un proceso de depuración de sus desviaciones, sombras y vacíos, pero siempre con un sentido de verdad, tal como guiaba los juicios sobre las representaciones sacras con mirada inquisitorial. Finalmente, cabe recordar que imaginar es

${ }^{9}$ El propio Herrera hace uso de esta noción, entre otros pasajes, en el soneto CIV del libro I, al pintar el modo en que se imprime en su ánima el rostro de la amada: "Aquel sagrado ardor que resplandece / en la belleza de la Aurora mía, / mi espíritu moviendo, al pecho envía / la pura imagen que en mi alma crece". Y reitera en la elegía II, 5, con un ubi sunt dedicado a las prendas de la amada: "¿A dó la perfección nunca imitada / de aquella imagen viva y hermosura, / con inividia de todas admirada?”. 
producir imágenes, tal como hace el imaginero, trasladando a la materia el modelo ideal; con este sentido lo registra Autoridades ("disponer con imágenes, o adornar con ellas alguna pieza de arquitectura"). Comparando su edición con sus pinturas, Pacheco querría haber dejado su sello, una firma secundaria, y esto le lleva a recurrir al concepto pictórico para complementar la noción de "forma verdadera" (también relacionada con el campo de las artes visuales) y explicitar su matizada intervención, sin que en ningún caso debamos suponer que alude a una invención fabulosa que produce un monstruo irreal con los disjecta membra de los papeles herrerianos. Como cualquier editor, hubo de revisar los textos y tratar de eliminar deturpaciones o vacíos, pero lo haría, de la manera más probable, respetando la forma original, sobre todo en lo que se refiere a su estructura. Y esto es lo que trasladó a la imprenta, tras copiarlo repetidas veces de su mano, como indica Duarte.

Como complemento y, en cierta medida, como confirmación de lo expuesto, el lector encuentra junto al soneto un grabado con la imagen retratada de Fernando de Herrera. Antes de entrar en su consideración conviene detenerse en la composición material de esta parte del libro. Los tres pliegos de preliminares se concluyen con la prefación herreriana y se cierran con el grabado que lleva la marca tipográfica de Estupiñán. Tras ellos, como con una consideración distinta - hipótesis que considero más verosímil que la de un error en la cuenta o un añadido a posterior $i^{10}$-, se incluye medio pliego de impresión exclusivamente para el soneto y el retrato, dejando dos páginas en blanco entre ambos. Lo inhabitual de este desperdicio de papel encuentra una explicación en que de tal modo el retrato queda, abierto el libro, en la página contigua a la del comienzo del libro I, ya en otro pliego, como era uso corriente. La imagen de Herrera es una copia de la plasmada en el Libro de retratos, hecha, a su vez, sobre la vera effigies del poeta, en un juego de reproducciones en el que la imagen puede depurarse, pero no deturparse. El cambio - aparte del marco- procede de la inversión sobre el eje vertical, debida a todas luces a que el grabador Pieter Perret sacó la plancha sobre el modelo, que quedó al revés al reproducirse en el papel, y me parece que no fue un error, sino algo intencionado, como confirmaría la correcta reproducción del lema (agit in lucem veritatem tempus, que tam-

${ }^{10}$ No es descartable, en cambio, que sirviera para una circulación exenta. 
bién insiste en la idea de verdad) y según puede desprenderse del hecho significativo de que la mirada del poeta retratado se dirija a sus versos, en la página de la derecha.

Por su condición y su posición, el retrato forma pendant con el soneto en una forma de autorización de la edición y de su responsable, que dibujó al autor y administró sus versos con idénticas pretensiones de veracidad. De la misma manera, el soneto hace pareja con la dedicatoria a Olivares, pues se trata de otra forma de encomienda, en este caso, al público lector y con argumentos semejantes: el mismo Herrera que se integraba en la galería de "ilustres y memorables varones" del Libro de retratos se presentaba como un motivo para que la "nación osada" tuviera un "nombre ilustre y generoso" que "no invidie ya otras liras más valientes / ni del latino o griego la grandeza" (Herrera $1619, * 1 r)$. El paralelo con la afirmación al noble de que su empresa va "encaminada sólo a que viva la memoria de los varones que ilustran nuestra nación y patria" es evidente, y el soneto desarrolla la idea con el tópico del parangón con Garcilaso, en el que se mide Herrera, no respecto a los ingenios contemporáneos. Así, el Betis se presenta como el legítimo heredero del Tajo, y la edición se convierte en una reivindicación de la tradición sevillana, viva en los participantes de tal empeño.

\section{Un contexto de edición}

La recuperación de la obra herreriana procura en el modo apuntado, al tiempo que la canonización individual, una afirmación colectiva, en eco atenuado de las Anotaciones, y, como éstas, busca proponer un programa poético. ¿Qué es lo que lleva a Pacheco, respaldado por su círculo, a volver a la propuesta de Herrera en estos momentos ya alejados de su muerte para convertirla en una bandera? ¿Y cuál es esta bandera? Intento formular una hipótesis de respuesta recogiendo algunos hilos argumentales ya apuntados. El influjo de la poética gongorina sería visto menos como una amenaza que como un último paso en la instauración de una poética cultista, en la que Herrera ocupaba un lugar de privilegio. Y no sería ésta la nube más amenazante sobre el declinante solar poético sevillano. En los años últimos del reinado de Felipe III Madrid completaba su papel de centralidad, primero geográfica, más tarde cortesana y, a su impulso y al del "monstruo de la naturaleza", también la 
sociocultural, con un nuevo modelo de sociabilidad y prácticas literarias que eclipsaba el de la academia sevillana del Quinientos. A la corte había sido atraído el propio Góngora, no tardaría en hacerlo Jáuregui y, poco después, Rioja, entre otros ingenios - el yerno del pintor entre ellos- que siguieron la estela del propio Olivares, cercano a su ascenso a la privanza.

De entrada, es preciso enmarcar la edición de Versos en un escenario más amplio, relacionado con la actividad de Pacheco. Desde su llegada a Sevilla, el mismo año que aparecían allí las Anotaciones, tomaría como referente a su tío el canónigo homónimo, quien lo acogió y lo puso en contacto con los círculos cultos en continuidad con la tradición académica de las décadas anteriores. Antes de acabar el siglo había dado inicio a su Libro de retratos, como registro de la república letrada hispalense, en que la galería de semblanzas individuales dibujaba de manera implícita una línea de continuidad y la dotaba de un aura de grandeza, por número y calidad de sus integrantes, fueran o no naturales de la urbe (Cacho Casal 2011). En las primeras décadas del siglo ya habría iniciado la elaboración de varios cartapacios en los que recogía distintas facetas de la producción sevillana, fuesen muestras de la "poesía de la sal", fuesen obras de erudición, cancioneros de varios o compilaciones de las obras de un solo poeta, como para el caso de Rioja, Baltasar del Alcázar o el propio Herrera, del que también compiló los textos relacionados con la polémica suscitada por las Anotaciones (Montero 2016), y ya hemos mencionado el propósito de editar otros textos de este poeta después de 1619. En él reconocería Pacheco el más alto ingenio lírico y la figura más descollante en el panorama de las letras sevillanas, además de servir de enlace entre las generaciones de mediados del siglo Xvi y las que florecían a comienzos del siguiente, cuando sobre el panorama se cernían sombras de decadencia.

Hasta 1615 don Gaspar de Guzmán había mantenido la llama en las reuniones de hombres de letras en el Alcázar del que era alcaide; sin embargo, ese año marcha a la corte como gentilhombre del futuro Felipe IV, antes de convertirse en su todopoderoso valido. Sevilla perdía así su mecenas más importante e iniciaba una paulatina sangría de ingenios atraídos por la corte o directamente llamados por Olivares. El mismo año de Versos Jáuregui ya está instalado en Madrid, y allí le seguirán Rioja, Fonseca y Figueroa, Francisco de Calatayud o el conde de la Roca (Montero 2012). A la descapitalización sevillana se unía 
la expansión sociocultural madrileña, y la polaridad entre centro y periferia se invertía respecto a medio siglo atrás, como una grave amenaza para la otrora floreciente metrópolis, perdido también el empuje que representó la Casa de Contratación. La casi simultánea solicitud de licencias de impresión por Pacheco y por Jáuregui podría leerse en clave de sendos intentos, posiblemente no coordinados, de avivar los rescoldos del antiguo esplendor, con una propuesta netamente sevillana en su origen y en sus claves poéticas, la de las Rimas más atenta a los nuevos vientos estéticos, y en la de Versos patente la voluntad de recuperar unas líneas que otorgaron distinción (Bourdieu 1988).

$\mathrm{Si}$ atendemos al tono con que Rioja y Duarte respondieron a la solicitud de preliminares, cabe considerar la edición de 1619 como un empeño personal de Pacheco, cuyo entusiasmo arrastraría a sus colaboradores con más eficacia que una menguada devoción por la lírica del antepasado. También pudo pesar la dedicatoria del volumen a Olivares, aunque el puente con la corte que el pintor pretendía fuese finalmente un camino de salida, particularmente para Rioja, quien vio recompensado en breve plazo el ofrecimiento particular que hizo de su texto al conde-duque. De una u otra forma, el síntoma de la decadencia anunciada con la marcha de Olivares a la corte debió de ser el resorte definitivo de la decisión editorial de Pacheco. Ciertamente, la labor de búsqueda y recomposición de lo que quedó de la obra de Herrera pudo haberse iniciado con anterioridad, en un proceso teñido con los colores de lo arduo. Si el interés por publicar su poesía se hubiera iniciado más cerca de la muerte de Herrera ${ }^{11}$, resulta extraño que no quedara de esta labor algún testimonio manuscrito parejo a los citados. No son datos concluyentes, pero permiten sostener la hipótesis de que la tarea de Pacheco bien pudo ser más limitada en el tiempo ${ }^{12}$, y ello sólo hubiera sido posible contando con un material bastante amplio y con una cierta ordenación. Si lo que conocemos del verso de Pacheco no condice con su capacidad de corregir los

11 A ello apuntan algunos indicios, como la inclusión en las Flores de Espinosa del soneto de Baltasar de Escobar colocado en Versos entre los libros segundo y tercero y que tiene rasgos de composición laudatoria para una edición. Juan Montero ha reunido otros datos y prepara un trabajo que supone un adelanto significativo de la fecha de inicio de las tareas de edición.

${ }^{12}$ Me refiero en exclusiva a la labor filológica y de erudición, no a todo el proceso que llevaría el resultado a la imprenta, incluidas la decisión de hacerlo y la disponibilidad de los recursos necesarios. 
textos herrerianos en una línea de acentuación del cultismo y la presunta decantación barroca, menos cabe esperar del supervisor de la ortodoxia de las imágenes y del devoto de Herrera una intervención de mayor calado, como la que tiene que ver con una infrecuente organización del volumen, con su división en tres libros y la intensa y poética articulación de éstos que se desprende de una lectura con un poco de atención.

En conclusión, avanzamos en la hipótesis de que Pacheco contaría con una base sólida para un proyecto de edición que debió de moverse con un impulso muy concreto y localizado. Se trataría de un armazón previo, más o menos completo en el testimonio conservado, y que sólo podría proceder del estro herreriano y su profunda reflexión sobre la poesía, en la clave continuada de una empresa nutrida en el horizonte de agotamiento del petrarquismo como modelo dominante. La originalidad de la propuesta, su escasa sintonía con las líneas poéticas del momento, en una aceleración pronunciada en las décadas en torno al cambio de siglo, y, en última instancia la falta de apoyo de Olivares - más allá de una posible contribución financiera a los costes de impresión-y del entorno cortesano debieron de estar en la base de la escasa trascendencia de Versos en los momentos que siguieron a su aparición; el olvido se tradujo en falta de aprecio y, finalmente, en las suspicacias críticas sobre su originalidad, hasta dejar al margen de la construcción historiográfica la singularidad de la propuesta, su original diseño y la diferencia que presenta, a uno y otro lado, con el modelo petrarquista y con volúmenes colocados bajo el signo del amontonamiento como el Tesoro de Padilla o la compilación de López Maldonado.

\section{LA ORDENACIÓN EDITORIAL}

El precedente de Algunas obras y su relación con la lectura crítica de Garcilaso y, sobre todo, de la fosilización del petrarquismo han de situarse en la base de la lectura interpretativa de Versos, comenzando por su particular disposición. Begoña López Bueno (2007 y 2014) ha insistido en la peculiaridad de una ordenación del cancionero de 1582 que supera la linealidad característica del iter petrarquesco a favor de una estructura de circularidad ${ }^{13}$; con ella se generan tensiones significativas no

${ }^{13}$ Han propuesto lecturas matizadamente distintas Pepe SARno (1990) y Álvarez (2008). 
resueltas, y en ellas cabe ver una primera manifestación de las que atravesarán el volumen de 1619 en su peculiar ordenación.

Otras ediciones póstumas en las tres décadas anteriores muestran un perfil completamente distinto. Por citar tres casos, las de Gregorio Silvestre (1582) y Hernando de Acuña (1591) presentan un carácter completivo o casi tal, y en ellos se nota la mano del editor, más clara y "profesional" cuando se trata de Pedro de Cáceres para el primero y menos sistemático cuando es la viuda de Acuña la que interviene, pero en los dos con opciones dispositivas a tono con los modelos vigentes en el momento; y, en una cronología más cercana, la descuidada impresión de los versos de Hurtado de Mendoza (1610) deja bien a las claras la sustancial diferencia con el caso de Herrera: con similares problemas textuales, la dispositio no responde a ningún patrón apreciable. No es necesario recurrir a esta comparación para percibir los nítidos perfiles de Versos, comenzando por el proceso de selección aludido por Rioja. No obedece la exclusión de los poemas señalados a una cuestión de calidad, ni siquiera en el caso de una posible minusvaloración de los octosílabos, porque ello no sería aplicable a las églogas ni al Lausino y Corona. La razón más admisible es el propósito de acentuar la coherencia de lo seleccionado para componer un volumen orgánico, ya con la selección de los metros (en lo que ellos tienen de modalidades genéricas), ya con la gran unidad temática en el eje del discurso central, por más que se entreveren elementos episódicos, con menos carácter de digresión que de contrapuntos o perspectivas complementarias o contextuales. No en balde, la propia denominación de "libros", escogida y subrayada en los titulillos de página, remite, en lo contemporáneo, a la terminología de la prosa, en coherencia con el fuerte elemento de narratividad que atraviesa toda la colección (Ruiz Pérez 2021) y enhebra un libro con otro.

Existe, es cierto, un precedente de importancia: el que presenta el volumen de Boscán en 1543, también finalizado póstumamente por la viuda; siguiendo sin duda el diseño del propio poeta, también distribuye su obra en tres libros. Las diferencias, sin embargo, son evidentes, pues aunque en los tres la materia amorosa es dominante, se separan con claridad en metros, estilo y aun en la filografía que los sostiene, con cambios menos vitales que poéticos. No es el caso de Herrera, que con la permanencia constante de sonetos, elegías, canciones y, en el primer libro, sextinas y estancias establece un discurso sostenido, 
donde las variaciones tejen la mencionada narratividad sobre la experiencia de un yo poético modulado, pero continuo. Existe un minucioso trabajo de secuenciación, apoyado más que obstaculizado por la articulación, en una labor que difícilmente cabe atribuir con fundamento a una hipotética manipulación de Pacheco. Ni resulta acorde con sus capacidades ni tampoco con su actitud respecto a la obra de Herrera; en cambio, sí es de gran coherencia con el poeta en atención a su poética y a su cuidado casi obsesivo por la elaboración y el resultado final de sus textos.

Estamos, y esto ha merecido poca atención de la crítica, ante una fórmula novedosa, como novedoso era que un poeta volviera sobre poemas ya publicados ${ }^{14}$, para reordenarlos en una estructura de mayor complejidad, no sólo por el muy amplio número de piezas y de versos. Si no completiva, la edición se presenta como una decantación de la labor de muchos años que incluye y reorganiza textos ya impresos. El extenso corpus reclamaba algún principio de segmentación, pero, por la misma causa, también propiciaba el abandono del principio de unidad, en especial en unos años (los finales de la escritura y los de la edición) en que se iba imponiendo el de la varietas, tal como no tardaría en trasladarse al espacio del poemario impreso con la entrega de $L a$ Filomena por Lope. Sin embargo, la heterogeneidad queda reducida a su mínima expresión en términos estrictamente descriptivos, tanto en la métrica como en el asunto, y en ambos casos lo que se impone no es la monotonía o el adocenamiento, sino la capacidad de dotar sus matices de importantes repercusiones.

Así ocurre, y esto es más conocido, en la reordenación y resemantización de los géneros poéticos, en particular con el desplazamiento de la elegía a la función desempeñada en el modelo de Petrarca por las canciones, mientras éstas adquirían un valor pindárico colindante con una épica en importante medida evocada también con la división en libros (López Bueno 1994). Así se extendió desde mediados de siglo el notable modelo de la versión castellana de La Odisea, el prestigioso texto homérico con ecos de batallas e impulsos de retorno, de acercamiento al hogar perdido en una sucesión de acontecimientos y caídas ${ }^{15}$.

${ }^{14}$ El único precedente de relieve es el de Jorge de Montemayor.

15 Son elementos que se pueden apreciar en el discurso poético de Versos, en cuyo libro tercero el soneto XCV alude al episodio de las sirenas y muestra al amante-poeta como un nuevo Ulises (Ruiz Pérez 2021). 
Por los años en que los humanistas buscaban en la obra de Heliodoro un modelo para la narrativa idealista, De la Ulixea de Homero, trece libros traducidos de griego en romance castellano por Gonzalo Pérez (Amberes, 1550) redefinía la naturaleza del héroe y su epopeya, en términos más humanos, con más impulso unitivo que destructivo. Sin postular una inequívoca influencia directa, una obra de estas características y relevancia pudiera latir bajo la decisión de ordenar en libros un diseño unitario, donde la progressio no implica ruptura, sino una depuración del sujeto poético y de su experiencia, sin que la lógica del movimiento narrativo anule el principio esencial de la recursividad en la lírica.

La doble dimensión de Versos puede ponerse en relación con el sentido vivencial que le ha sido atribuido y enriquece la dimensión de intimismo que Begoña López Bueno (2014, pp. 13-18) ha destacado en la poesía herreriana. Su profundo sentimiento lírico ${ }^{16}$ avanza en una dirección divergente a la línea mayor de una poesía en deriva desde la introspección de la subjetividad renacentista a la proyección pública, la atención a la realidad exterior y la construcción de la apariencia barroca. Su componente épico-narrativo ${ }^{17}$ se potencia y hace más apreciable por la propia extensión del corpus, la continuidad de su asunto y la articulación en libros. La magnitud expresa la distancia de Versos respecto al desahogo sentimental, muy unido a la circunstancia, requiere de manera inexcusable un principio de articulación y ordenación, y otorga una dimensión proyectiva al elevar la anécdota a categoría. En el mismo número que los poemas/días del ciclo del Canzoniere, los 365 poemas originales ${ }^{18}$ de Versos, desde la neutralidad del título ${ }^{19}$, permiten

${ }^{16}$ No le resta intensidad el que se sitúe más cerca del "secreto artificio" del fonosimbolismo pontaniano (Vega Ramos 1992; Ferguson 1981) que al de la musicalidad sentimental.

17 No me refiero específicamente al tono y la materia de sus canciones heroicas, sino a la elevación de su propósito y estilo respecto al iter petrarquista, con lo cual explota la narratividad que Prieto (1989, pp. lx-lxi) pone de relieve en la secuencia de sonetos a partir del Canzoniere. Véase Ruiz Pérez (2021) para una exposición más detallada.

18 Libro I, 144 (121 sonetos, 12 elegías, 5 canciones, 4 sextinas y 2 composiciones en octavas); libro II, 130 (111 sonetos, 12 elegías y 7 canciones); libro III, 91 ( 76 sonetos, 9 elegías y 6 canciones). No entran en el cómputo los poemas ajenos; de tomarlos en cuenta se desborda el límite petrarquesco.

${ }^{19}$ Lo genérico de la denotación no borra la fuerte connotación que el título adquiere al separarse de manera evidente de los títulos habituales para 
la trascendencia de lo que podría quedarse en los límites de una experiencia amorosa de expresión lírica o, más claramente, mélica, en la distinción herreriana. El discurso del poeta la proyecta a una altura mítico-épica, donde se plasma su concepción de la lírica sensu stricto y la acerca a los límites de la tragedia a partir de lo que se presenta como un caso de hybris y se despliega en términos de ascenso y caída (Ruiz Pérez 1997 y 199697; Álvarez 2019).

De la tragedia, como género y modalidad, el poemario final de Herrera retiene la noción de destino, la dimensión heroica del sujeto poético y el sentido del drama como pugna y conflicto. Un todavía notable sentido del aptum apoya en este claro trasfondo trágico la elevación estilística que reclamaba tanta justificación por parte de Rioja y Duarte ${ }^{20}$ y que no cabe entender en los límites de una estrecha y escolar consideración del Barroco, ni tampoco imputar a presuntas manipulaciones de Pacheco. Asimismo, el sentido trágico se traduce en lo que también López Bueno (2014) considera el carácter "vivencial" de la poesía de Herrera, una brillante y a contracorriente apreciación crítica, absolutamente pertinente si no se pretende reducir a una lectura anecdótica y referencialista, ligada a un concreto y biográfico episodio de enamoramiento y frustración. Se trata, a mi juicio, de algo más radical, porque atañe a las raíces de la condición humana. A este respecto, cabe hablar de un sentido existencial de la experiencia poética ${ }^{21}$, que bien podría rotularse de "existencialista" de no incurrir en un anacronismo y que quizá se explica mejor en los valores clásicos de la tragedia a los que he aludido y que he desarrollado en otro lugar (Ruiz Pérez 2021).

Valga ahora con estas consideraciones para seguir sustentando la tesis de que la construcción del discurso de Versos es netamente herreriana y no obedece a una intervención espuria, que difícilmente podría haber compuesto desde fuera un conjunto orgánico a partir de "rime sparse" e inconexos restos de un naufragio — si ésta es la uña, ¿cómo sería el león? Su

\footnotetext{
los volúmenes líricos en las décadas finales del siglo XVI y primeras del XVII, dominados por rótulos como Obras, Poesías y Rimas. Véase al respecto García Aguilar (2008, pp. 215-250 y 289-306).

${ }^{20}$ Como en 1618 lo había hecho Jáuregui en el preámbulo de sus Rimas.

${ }^{21}$ Lo apunta también así MACRí (1972, pp. 37-38); en las mismas páginas, y en diálogo con las tesis de Coster (1908), añade consideraciones sobre la dimensión épica antes mencionada.
} 
perfecto encaje y lo poliédrico del resultado no podrían haber sido fruto del azar de una transmisión o de manejos ajenos, de no haber existido una completa articulación y ordenación previa. El resultado de mano de Herrera pudo verse afectado, con una diferencia de intensidad, por los inevitables avatares en la transmisión y los distintos grados de manipulación en el paso de la idea al manuscrito y de éste a la imprenta. Sin embargo, "sus obras poéticas, que él tenía corregidas de última mano y encuadernadas para darlas a la imprenta" (Herrera 1619, ††3r), según la noticia de Duarte, debieron de permanecer en su definición esencial.

Operamos sobre un texto esencialmente herreriano, aunque suspecto en cuanto a su estricta fidelidad al original evocado por Duarte, que sitúa en el gabinete del poeta la labor de reconstrucción textual atribuida a Pacheco por parte de la crítica. Frente a los argumentos de ésta, el texto prologal desmiente o, cuando menos, cuestiona el alcance de su intervención al tratar del preámbulo autorial; el detalle habla más de soberbia que de discreción editorial:

Y con deseo de que no se perdiese el trabajo de un pequeño papel que acaso hallé entre los míos, escrito de letra de Fernando de Herrera, de unos periodos desatados que parece juntaba para formar alguna pequeña prefación de sus Versos ${ }^{22}$, quise yo formarla de los mesmos centones o partes; si pareciere bien, será por los vestigios que en ella hubieren quedado de su verdadero dueño, y, si mal, por ignorancia mía.

La afectada modestia final no encubre la contraposición previa entre la pobreza de lo debido a Herrera ("pequeño papel",

22 Así aparece luego rotulado el texto, "Prefación de Fernando de Herrera a sus Versos" - y respeto también en este caso el uso de la mayúscula. La coincidencia del sintagma y el uso de la tercera persona inducirían a considerar el rótulo como obra de Duarte, lo que nos devuelve al problema del título y su autoría herreriana. No es descartable que estuviera ya en la mente de Herrera, si pensamos en una intencionalidad significativa. Sin embargo, sobre los señalados valores de neutralización y opacidad, el rótulo apunta también una tendencia disgregadora e inorgánica, que considero opuesta a la naturaleza de la obra. Es difícil decantarse, porque el punto pudo quedar pendiente de una decisión final; si existió con un sentido distinto, pudo perderse o pudo merecer la desconsideración del editor, que no quisiera centrar o iniciar en este punto el impulso novedoso de la propuesta herreriana. Queda pendiente la resolución de consideraciones más detenidas. 
encontrado "acaso", "periodos desatados", "parece que juntaba", "pequeña prefación", "centones") y la importancia del propio Duarte ("deseo de que no se perdiese", "mis papeles", "quise formar"). No son indicios de un transmisor riguroso y sincero, pero sirven para darle la razón a su última afirmación citada: por mucho que se quiera sembrar duda, la prefación "parece bien" y muestra la huella de su verdadero autor.

Con este criterio ha de analizarse el contenido de la declaración proemial herreriana, que confirma otras manifestaciones contenidas en la propia edición y las observaciones e hipótesis realizadas a partir de ellas. Su brevedad y aparente carácter convencional no acaban de encubrir su densidad, sobre la que sustentamos la autoría de Herrera. A modo de un único párrafo relativamente extenso, el texto encadena condicionales y adversativas para una retórica de la reticencia; sin embargo, se pueden distinguir dos componentes o partes en una disposición envolvente que cuestiona la convencionalidad de algunas afirmaciones. El núcleo central y más extenso, con una coletilla epilogal, lo ocupa una especie de recusatio invertida, en la que hallamos ecos de una actitud frecuentemente textualizada: se enfrenta una voluntad de resistencia a la imprenta, con amplia base de realidad, y la obligación debida a la obediencia, índice de la persistencia del modelo de relaciones de mecenazgo. A esta gramática conceptual pertenece ese otro locus communis, asentado en los comentarios virgilianos y su sistematización de los procesos de escritura, que vincula la práctica de la lírica con los "juegos de la juventud"; sin embargo, la sintaxis en que aparece la expresión establece la frontera con la parte más reflexiva y personal del prólogo, situada en su arranque mismo y cerca del final.

Vemos en esta parte-marco lo consciente del ejercicio herreriano y lo ajustado a la realidad que observamos en el texto introducido por estas palabras. Ante todo desataca la rotundidad de la manifestación "me dispongo... a publicar", donde el "tan tarde" neutraliza la consideración de "juegos de la juventud", al trasladar el foco temporal a la madurez de la decisión, con lo que impone sobre la inventio inicial una voluntad reorganizadora y, sobre todo, resemantizadora, porque quien ahora asume la decisión de publicar no es el mismo joven que creó inicialmente los versos, y no sólo porque ha pasado el tiempo y han podido llegar las canas. El juego queda diluido de inmediato en una empresa de búsqueda "de la perfeción y ecelencia que se halla en la obra de los buenos escritores" ( $\dagger \dagger+4 r)$, 
que saca los versos de la expresividad inmediata para convertirlos en una trabajada realización, de cuyo carácter presumiblemente da cuenta la elección del término escritores en lugar de poetas: esto último se da por asumido a partir de la inspiración que ha movido el canto, pero ahora se trata de fijarlo en escritura, de hacerlo una obra de arte tal como quedaba metaforizado en la labor con el textus de las ninfas de la garcilasiana égloga III (Egido 2003): lo natural se convierte en artificio o, por mejor decir, trasciende su realidad más inmediata por medio del artificio. La naturaleza de éste se apunta cuando se precisa quiénes son "los buenos escritores" y el modo en que Herrera se mira en ellos: "por acercarme a la perfeción con la imitación de los mejores" el poeta ha acudido a "estudio y trabajo" y se ha movido por "admiración de los antiguos" ( $\dagger \dagger 4 \mathrm{v}$ ).

El argumento del estudio y el trabajo se distingue de las más frecuentes apelaciones al impulso del estro o la natura y al dominio del ars; apunta a una poética erudita o culta, esto es, que surge del esfuerzo por desbrozar y cultivar; y, de manera más específica, traslada a la declaración y le da carta de naturaleza al ejercicio de pulimento y reescritura, que no hay que reducir sólo al nivel de lo microtextual o estilístico. También alude a la reelaboración de los materiales, incluida su ordenación, y señala un horizonte bastante claro, al menos en lo que niega, pues la propuesta de Versos se acerca más a los modelos clásicos grecolatinos ("los antiguos") que a los imperantes en su momento (Ruiz Pérez 2021).

Aunque fuese un "pequeño papel”, Herrera fija muy bien en sus líneas los principios de su tarea cuando ésta alcanzaba su configuración última: se trata de una revisión desde la madurez, vital y creativa, de su obra anterior, para acercarla a una propuesta que asienta su novedad en la revitalización de un modelo poético de resonancias clásicas. Así, sin abandonar el argumento amoroso y su formulación en clave neoplatónica, lo dota de una fuerte polisemia simbólica con un elevado componente metapoético, apoyado en las imágenes del deslumbramiento y la persecución de la luz, signada por los motivos de la elevación y la caída y, finalmente, por la trascendencia del canto y su elevación a una altura heroica. Un destino inflexible amenaza con retenerlo en este ciclo infinito, contrario al iter petrarquista. Sólo de una cierta aceptación surgirá una posible vía de salida, y en la formulación de esta experiencia trágica desempeña una función fundamental la división tripartita. 
Este molde sostiene la revisión del petrarquismo boscaniano, coronando los pasos de las Anotaciones y Algunas obras y en sintonía con el desarrollo de la poética cultista en el cambio de siglo. Rehusando la división de los libros por metros-género, Versos mantiene la presencia del argumento amoroso, aunque en presencia decreciente, y se orienta en el último libro a una poesía de proyección pública, que justifica en su materia y destinatarios la elevación del estilo. La consecución de este ideal en la poética herreriana quedaba asumida en las palabras de Duarte y justificaba la referencia de Pacheco a un "grande canto" y a su valor de honra para la "nación osada". Por más que la solución adoptada por Herrera en los años finales de su vida y del siglo xvi se diferenciara de las extendidas tras la aparición del Polifemo y las Soledades, apuntaba en una dirección coincidente, y no sólo en los puntos señalados. La actitud de Herrera en la labor de reordenación de sus poemas confirma el perfil de un poeta de gabinete, que tiene tanto de legado del modelo humanista como de avanzada en la construcción de un nuevo perfil autorial, que en el caso de la poesía lleva de la versificación de circunstancias (la amorosa incluida) a la tarea escritural y editorial de composición de un libro (o de una agrupación orgánica de libros) definido en el escenario y molde de la imprenta, con todas sus implicaciones.

En conclusión, el análisis de la materialidad del volumen de Versos y las consideraciones sobre un contexto de edición aún no esclarecido completamente revelan una complejidad que incluso sobrepasa a la de la problemática textual tal como se ha venido delimitando. Sin tener plena certeza de en qué momento Pacheco inicia su empresa y de qué obstáculos encontró en su camino, parece indudable que la situación sociocultural de Sevilla y su horizonte inmediato obraron en el impulso definitivo poco antes de la solicitud de licencia. Las limitaciones económicas y técnicas se reflejan en la demora de tres años y en el escaso brillo tipográfico, respectivamente. Por el contrario, destaca en este marco el acusado sentido estructural de la articulación en tres libros y su correspondiente marca en los titulillos del volumen, con una decisión editorial fuerte, que no parece propia de la labor de Pacheco. Las declaraciones prologales, generalmente tomadas en lo tocante al "naufragio" póstumo y la labor compi- 
ladora de Pacheco, contienen también afirmaciones más desatendidas en las que se hace patente que Herrera dejó ultimado para la imprenta un cuaderno ordenado y corregido. De haberse conservado en su integridad, la edición final no hubiera presentado algunos de sus indiscutibles descuidos (composiciones repetidas, versiones desechadas o desechables...), atribuibles a las limitaciones de Pacheco. Con todo ello no es sostenible que el pintor no trabajara sobre una base suficientemente sólida de procedencia herreriana. Así, si en la conformación que ha llegado a nuestras manos aparecen inequívocas sombras, tampoco nos cabe duda de que en el proceso de composición editorial de una obra concebida unitariamente desde el final del camino poético los rasgos principales corresponden a la "forma verdadera" que quiso disponer Herrera.

\section{REFERENCIAS}

Álvarez, Javier 2008. "Iter ad caelum: amor y poética en Herrera”, en Cánones críticos en la poesía de los Siglos de Oro. Ed. Pedro Ruiz Pérez, Academia del Hispanismo, Vigo, pp. 169-178.

Álvarez, Javier 2019. "Imágenes de la osadía en la lírica de Fernando de Herrera”, Caliope, 24, 2, pp. 109-127; doi: 10.5325/caliope.24.2.0109.

Autoridades = Real Academia Española, Diccionario de autoridades, Gredos, Madrid, 1963 [1726-1737], 3 ts. [Ed. facs. de la Impr. de Francisco del Hierro, Madrid.]

Blecua, José Manuel 1970. "De nuevo sobre los textos poéticos de Herrera", en Sobre poesía de la Edad de Oro. Ensayos y notas eruditas, Gredos, Madrid, pp. 110-144. [Artículo publicado originalmente en el Boletín de la Real Academia Española, 38 (1958), pp. 337-408].

Bourdieu, Pierre 1988. La distinción. Criterios y bases sociales del gusto, Taurus, Madrid.

Cacho Casal, Marta 2011. Francisco Pacheco y su "Libro de retratos", Fundación Focus Abengoa-Marcial Pons, Sevilla-Madrid.

Chiappini, Gaetano (ed.) 1985. Fernando de Herrera y la escuela sevillana, Taurus, Madrid.

Coster, Adolphe 1908. Fernando de Herrera (El divino). 1534-1597, Honoré Champion, Paris.

Covarrubias, Sebastián de 1979. Tesoro de la lengua castellana o española, Turner, Madrid.

Cuevas, Cristóbal 1985. "Introducción”, en Fernando de Herrera, Poesía castellana original completa, Cátedra, Madrid.

Darst, David H. 1985. Imitatio. (Polémicas sobre la imitación en el Siglo de Oro), Orígenes, Madrid.

Domínguez GuzMán, Aurora 1992. La imprenta en Sevilla en el siglo XVII: catálogo y análisis de su producción, 1601-1650, Universidad de Sevilla, Sevilla. 
Egido, Aurora 2003. "El tejido del texto en la égloga III de Garcilaso", en Garcilaso y su época: del amor y la guerra. Eds. José M. Díez Borque y Luis Ribot García, Sociedad Estatal de Conmemoraciones Culturales, Madrid, pp. 179-200.

Escudero y Perosso, Francisco 1999. Tipografía hispalense. Anales bibliográficos de la ciudad de Sevilla. Ed. facsímil de Ayuntamiento de Sevilla, Sevilla. [Repr. facs. de Est. Tip. "Sucesores de Rivadeneyra", Madrid, 1894].

García Aguilar, Ignacio 2008. Poesía y edición en el Siglo de Oro, Calambur, Madrid.

Ferguson, William 1981. La versificación imitativa de Fernando de Herrera, Tamesis, London.

Hernández Lorenzo, Laura 2020. Los textos poéticos de Fernando de Herrera: aproximaciones desde la estilística de corpus y la estilometría, tesis, Universidad de Sevilla, Sevilla, en https://idus.us.es/handle/11441/93465 [consultado el 9 de abril de 2020].

Herrera, Fernando de 1619. Versos, por Gabriel Ramos Bejarano, Sevilla.

Herrera, Fernando de 1908. "Algunas obras" de Fernando de Herrera. Ed. crít. de Adolphe Coster, Honoré Champion, Paris.

Herrera, Fernando de 1914. "Versos" de Fernando de Herrera. Ed. Adolphe Coster, Bibliotheca Romanica, Strasbourg.

Jáuregui, JuAn de 1618. Rimas, por Francisco de Lira Varreto, Sevilla.

López Bueno, Begoña 1994. "De poesía «lírica» y poesía «mélica»: sobre el género «canción» en Fernando de Herrera", en Hommage à Robert Jammes. Coord. Francis Cerdán, Presses Universitaires du Mirail, Toulouse, t. 2, pp. 721-738.

López Bueno, Begoña 2007. "Más sobre el orden de los cancioneros poéticos: el caso de Algunas obras de Fernando de Herrera”, Calíope, 13, 1, pp. $45-60$.

López Bueno, Begoña 2014 [1998]. "Estudio preliminar", en Fernando de Herrera, Algunas obras, Diputación de Sevilla, Sevilla, pp. 11-115.

López Estrada, Francisco 1955. "Datos sobre la poesía sevillana. Un inmediato comentario de las Rimas de Jáuregui (1618)", Archivo Hispalense, 22, 77, pp. 281-284.

Montero, Juan 2012. "Olivares y los ingenios andaluces. Sobre el mecenazgo literario del conde-duque", Andalucía en la Historia, 36 (número monográfico: El otro conde-duque. El mecenazgo de Olivares. Coord. Carlos Alberto González Sánchez), pp. 16-19; hdl: 11441/50397.

Montero, Juan 2016. "El pintor Pacheco y las letras sevillanas del Siglo de Oro”, en Pacheco: teórico, artista, maestro (1564-1644). Coord. María del Valme Muñoz Rubio e Ignacio Cano Rivero, Consejería de Cultura de la Junta de Andalucía, Sevilla, 2016, pp. 13-24.

Montero, Juan y Marta Cacho Casal 2014. "Francisco Pacheco, editor de obras de Fernando de Herrera: análisis de un documento inédito", Bulletin of Spanish Studies, 91, 4, pp. 491-504; doi: 10.1080/14753820.2014.886891.

Núñez Rivera, Valentín 2000. "1582. (Poesía, imprenta y canon)”, en El canon poético en el siglo XVI. Ed. Begoña López Bueno, Universidad de Sevilla, Sevilla, pp. 141-175.

Macrí, Oreste 1972. Fernando de Herrera, $2^{a}$ ed., Gredos, Madrid. 
Pepe Sarno, Inoria 1990. "Itinerario di un amore. Algunas obras de Fernando de Herrera come canzoniere", en Dialogo. Studi in onore di Lore Terracini, Bulzoni, Roma, pp. 479-493.

Prieto, Antonio 1989. "Introducción”, en Francesco Petrarca, Cancionero, Planeta, Barcelona.

Rico García, José Manuel 2001. "La perfecta idea de la altísima poesía”. Las ideas estéticas de Juan de Jáuregui, Diputación de Sevilla, Sevilla.

Ruiz Pérez, Pedro 1996-97. "La lírica de Herrera: mito y circunstancia", Glosa, 7, pp. 49-75.

Ruiz Pérez, Pedro 1997. "Mitología del ascenso en los sonetos herrerianos”, Ínsula, 610, pp. 6-9.

Ruiz Pérez, Pedro 2001. "Imprenta y poesía en Córdoba en el siglo XviI", en La cultura del libro en la Edad Moderna. Andalucía y América. Eds. Manuel Peña Díaz, Julián Solana Pujalte y Pedro Ruiz Pérez, Universidad de Córdoba, Córdoba, pp. 85-109.

Ruiz Pérez, Pedro 2011. "La edición zaragozana a mediados del siglo xvi y la sistematización del libro de poesía”, Bulletin Hispanique, 113, 1 (número monográfico: El libro de poesía (1650-1750): del texto al lector. Coord. Pedro Ruiz Pérez), pp. 69-101; doi: 10.4000/bulletinhispanique.1316.

Ruiz Pérez, Pedro 2021. "La construcción autorial de Herrera en Versos (1619)", en De Herrera. Estudios reunidos en el IV Centenario de "Versos" (1619). Eds. Juan Montero y Pedro Ruiz Pérez, Universidad de Sevilla, Sevilla, pp. 205-255.

Serés, Guillermo 1994. "El concepto de «fantasía», desde la estética clásica a la dieciochesca", Anales de Literatura Española, 10, pp. 207-236; doi: 10.14198/ALEUA.1994.10.10.

Valdenebro y Cisneros, José M. de 2002. La imprenta en Córdoba. Ensayo bibliográfico. Ed. facsímil, Diputación de Córdoba, Córdoba. [Repr. facs. de Est. Tip. "Sucesores de Rivadeneyra", Madrid, 1900].

Vega Ramos, M. José 1992. El secreto artificio. "Qualitas sonorum”, maronolatría y tradición pontaniana en la poética del Renacimiento, Consejo Superior de Investigaciones Científicas, Madrid. 